\title{
Analisis Studi Korelasional \\ Kecerdasan Emosional dan Minat Belajar dengan Hasil Belajar Pendidikan Agama Islam
}

\author{
Benny Prasetiya \\ STAI Muhammadiyah Probolinggo \\ Email: prasetiyabenny@gmail.com
}

\begin{abstract}
This study will analyze the quantitative correlation between emotional intelligence And interest in learning with the learning Results of education of Islam. data analysis was done using statistics: simple and multiple Regression, correlation, partial, and simple plural all. Prior to measurements performed on the significance level $\alpha=0.05$ testing the hypothesis of the study, first done test requirements analysis includes testing of its homogeneity and normality test. est of the significance of the correlation coefficients obtained from the Model Summary tabel contained on the first line of the correlation coefficient $=0.421$ and $\mathrm{F}$ count $(\mathrm{F}$ change $)=2.906$ with $\mathrm{p}$-value $=0.072>0.05$. This means that the $\mathrm{H} 0$ is rejected. R Square is the coefficient of Determination. The magnitude of $\mathrm{R}$ is Square $(\mathrm{R} 2)=0.177$ is $17 \%$. This means that the magnitude of the influence of emotional intelligence and interest in Learning learning outcomes against PAI 17\% and other variabels that affect the magnitude of the variabel results learn PAI is $83 \%$.
\end{abstract}

Keywords: Emotional intelligence, Interest to learn, learning outcomes, PAI

\section{Pendahuluan}

Rendahnya prestasi belajar peserta didik di sekolah menjadi persoalan bagi pendidik sebagai upaya menentukan batas minimal nilai yang diraih. Hasil prestasi belajar merupakan salah satu indikator keberhasilan dalam proses belajar mengajar. Menjadi hal yang sangat penting profesionalisme guru menjawab setiap masalah dan persoalan dalam kegiatan pembelajaran. Meskipun banyak teori menjelaskan bahwa banyak variabel-variabel yang memberikan kontribusi dalam peningkatan prestasi belajar.

Faktor yang menentukan prestasi belajar diantaranya faktor internal dan eksternal. Faktor internal merupakan faktor yang berasal dari dalam diri siswa, misalnya kecerdasan/intelegensi, kesehatan, emosi, motivasi, sikap, minat dan bakat. Sedangkan faktor eksternal berasal dari luar siswa seperti lingkungan belajar, kurikulum, pendidik, persiapan mengajar, sarana dan prasarana belajar dan lain-lain. Dua faktor inilah yang memiliki peran terhadap kontribusi pencapaian prestasi belajar. Sedangkan faktor yang memiliki peran yang cukup besar dalam proses pencapaian prestasi belajar adalah inteligensi. Semakin tinggi kecerdasan emosional siswa maka akan konstribusi peluangnya untuk mendapatkan prestasi belajar yang tinggi semakin besar begitu juga sebaliknya. 
Kehadiran minat belajar memberikan peran sangat penting dalam meningkatkan hasil belajar siswa. Siswa yang tidak mempunyai minat dan perhatian terhadap materi yang dipelajarinya maka akan mengalami kesulitan untuk membangun ketekunannya dalam mencapai hasil belajar. Sebaliknya, manakala siswa t belajar dengan mempunyai minat dan perhatian yang tinggi terhadap objek yang dipelajari, maka akan berdampak pada hasil belajar yang baik pula.

Peserta didik yang memiliki kecerdasan emosi memiliki kecenderungan untuk lebih besar untuk bisa memberikan ketenangan. Dalam pandangan Gottman (1997) remaja yang belajar dalam mengenali dan menguasai emosinya memiliki kecenderungan lebih percaya diri, lebih sehat secara fisik dan psikis. Hal ini berdampak pada kecenderungan menjadi orang yang sehat secara emosional.

Kecerdasan merupakan sebuah kemampuan umum seseorang dalam menyelesaikan setiap masalah yang dihadapi. Dalam pandangan Binet dalam Feldman yang merupakan tokoh inteligensi yang pertama, mendeskripsikan inteligensi sebagai monogenetik yaitu berkembangnya dari satu faktor atau faktor umum dalam tiga komponen yaitu : (a) Kemampuan dalam mengarahkan pola pikir atau mengarahkan tindakan, (b) Kemampuan dalam melakukan perubahan terhadap tindakan yang sudah dilaksanakan, dan (c) Kemampuan untuk untuk mengkritik diri sendiri1. Garrison dan Magoon Terman memberikan definisik inteligensi sebagai kemampuan untuk berpikir secara abstrak sedangkan Goddard mendefinisikan inteligensi sebagai kemampuan pengalaman dalam menyelesaikan masalah yang dihadapi dan merencanakan persoalan yang akan dihadapi ${ }^{2}$. Henmon dalam Azwar ${ }^{3}$ mendeskripsikan inteligensi sebagai daya atau upaya untuk memahami. Kecerdasan dapat dibedakan dalam dua kategori yakni : (a) kecerdasan nyata atau aktual, yang menunjukkan kepada aspek kecerdasan yang segera dapat didemotrasikan dan dapat diuji saat itu karena merupakan hasil usaha atau belajar; (b) kecerdasan potensial yang diperoleh dari bawaan yang mungkin merupakan kecerdasan dasar umum dan kecerdasan khusus dalam bidang tertentu ${ }^{4}$.

Shapiro dalam Aunurrahman kecerdasan emosional pertama kali dilontarkan pada tahun 1990 oleh psikolog Peter Salovey dari Harvard University dan John Meyer dari University of new Hampshire. Dalam pandangannya kecerdasan emosional merupakan himpunan bagian dari kecerdasan sosial dengan melibatkan kemampuan memantau perasaan dan

\footnotetext{
${ }^{1}$ Feldman, Robert., Understanding Psychology (Mc-Graw-Hill, New York: 1987.), 213

${ }^{2}$ Garrison, K.C. \& Magoon, R.A., Educational Psychology : An Integration of Psychology and Educational Practices (Charles E. Merril Publsing Company, Colombus:1972.), 82

3 Azwar, Syafuddin., Pengantar Psikologi Inteligensi (Yogyakarta: Pustaka Pelajar), 1996. h 6

${ }^{4}$ Makmun, Abin Syamsudin., Psikologi Pendidikan (Bandung: Remaja Rosdakarya), 1996.h39
} 
emosi diri sendiri dan orang lain, memilah-milah semuanya dan menggunakan informasi untuk membimbing pikiran dan tindakan. Dalam hal ini dideskripsikan bentuk-bentuk kualitas emosional yang memiliki peran dalam mencapai sebuah keberhasilan Di antaranya: (1) empati, (2) mengungkapkan dan memahami perasaan, (3) mengendalikan amarah, (4) kemandirian, (5) kemampuan Menyesuaikan diri, (6) disukai, (7) kemampuan memecahkan masalah antar pribadi, (8) ketekunan, (9) kesetiakawanan, (10) keramahan, (11) sikap hormat ${ }^{5}$.

Menurut Goleman ada lima Aspek kecerdasan emosi yang dalam pandangan Salovey dan Mayer pada tahun 1991) sebagai berikut:

a. Kesadaran diri yaitu kemampuan untuk mengetahui apa yang dirasakan pada suatu saat, dan digunakan dalam memandu pengambilan keputusan diri sendiri, memiliki tolak ukur realistis terhadap kemampuan diri dan kepercayaan diri yang kuat.

b. Pengaturan diri, yaitu kemampuan untuk menyelesaikan emosi sehingga memiliki dampak positif pada pelaksanaan tugas, memiliki kepekaan terhadap kata hati serta sanggup menunda kenikmatan sebelum keinginan terpacapai. Pada aspek ini memuliki kemampuan untuk kembali dari tekanan emosi.

c. Motivasi, yaitu kemampuan dalam menggunakan hasrat yang paling dalam mencapai keinginan. Bisa dikatakan pula sebagai aspek untuk membantu mengambil inisiatif sehingga bertindak efektif untuk bertahan menghadapi kegagalan.

d. Empati, adalah bentuk kemampuan merasakan apa yang dirasakan oleh orang lain, memahami perspektif mereka, menumbuhkan hubungan saling percaya serta menyelaraskan diri dengan bermacam-macam orang.

e. Keterampilan sosial, adalah kemampuan menangani emosi dengan baik ketika berhubungan dengan orang lain. Aspek ini pula memiliki kecenderungan dengan cermat membaca situasi, mampu berinteraksi dengan baik, menggunakan keterampilan sosial bekerja sama dalam suatu tim. ${ }^{6}$

Bar-On dalam Stein \& Book juga mendeskripsikan aspek-aspek kecerdasan emosi menjadi lima yaitu: (a) intrapersonal yaitu kualitas kemampuan dalam diri, meliputi kesadaran diri emosi, asertivitas, menghargai diri sendiri, aktualisasi diri, (b) interpersonal yaitu kualitas kemampuan dalam menjalin hubungan dengan orang lain, meliputi rasa

${ }^{5}$ Aununrrahman, Belajar dan Pembelajaran, (Bandung: Alfabeta), 2012. h. 85

${ }^{6}$ Ahmad Asrori, Hubungan Kecerdasan Emosi dan Interaksi Teman Sebaya dengan Penyesuaian Sosial Pada Siswa Kelas VIII Program Akselerasi di SMP Negeri 9 Surakarta .Skripsi.Surakarta.: Program Studi Psikologi Fakultas Kedokteran Universitas Sebelas Maret Surakarta.2009. h 29 
empati, hubungan interpersonal, tanggung jawab sosial, (c) cognition orientation merupakan pemanfaatan kognitif secara konstruktif dan realistik yaitu kemampuan menyelesaikan masalah, menguji kenyataan dan fleksibilitas, (d) stress management yaitu menjaga diri supaya tetap bisa mengendalikan diri dalam himpitan stres dari luar dan dari dalam atau dikenal dengan istilah toleransi stres dan pengendalian impuls, (e) affect merupakan sebuah perasaan positif dalam menumbuhkan kenyamanan dan kegairahan hidup yang meliputi kebahagiaan dan optimisme. ${ }^{7}$

Berbeda dengan pandangan Cooper dan Sawaf (2002) yang membagi kecerdasan emosi menjadi empat aspek diantaranya; 1). Ketrampilan emosi; yaitu pengelolaan emosi secara tepat dan efektif, 2). Keyakinan diri yaitu kepercayaan dengan menerima segala bentuk kelebihan dan kekurangannya., 3) Sudut pandang artinya kemampuan untuk memandang atau mempersepsikan sesuatu yang dengan dirinya sendiri, orang lain, maupun lingkungannya, 4). Kreativitas yaitu kemampuan dalam menciptakan ide, gagasan baru, sehingga dapat merubah sesuatu menjadi baik. ${ }^{8}$ Di samping kecerdasan emosional minat memiliki peran yang sangat penting memberikan dorongan terhadap hasil yang akan dicapai. Minat besar akan berpengaruh ketekunan terhadap objek yang diminatinya. Sebaliknya tanpa adanya minat akan membuat siswa tidak tekun dalam belajar. Elizabeth B. Hurlock mendefiniskan minat sebagai sumber motivasi yang mendorong dalam melakukan aktivitas sesuai dengan apa yang menjadi keinginannya"9.

Slameto memberikan pemahanan yang sama terhadap minat dimana suatu rasa lebih suka dan rasa ketertarikan pada suatu hal atau aktivitas tanpa ada yang menyuruh"10. Berdasarkan pendapat dari Slameto tersebut, minat pada asarnya merupakan penerimaan akan suatu hubungan antara diri sendiri dengan sesuatu di luar diri. Semakin kuat hubungan tersebut, maka semakin besar pula minat yang dimiliki. Sejalan dengan hal tersebut, Dengan demikian W. S. Winkel, memberikan penguatan dalam definisi ini dimana kecenderungan subyek yang menetap, untuk merasa tertarik pada bidang studi atau pokok bahasan tertentu dan merasa senang mempelajari materi itu”. Dalam pandangannya akan terjadi hubungan searah ketika perasaan senang dan minat, sehingga tidak mengherankan kalau siswa yang mempunyai perasaan tidak senang, maka akan menjadi kurang berminat ${ }^{11}$.

\footnotetext{
${ }^{7}$ Ibid..... 31

8 Ahmad Asrori, ... h 31

${ }^{9}$ Elizabeth B. Hurlock .Perkembangan Anak Jilid 2 . (Penerbit Erlangga, Jakarta : 2005), 114

${ }^{10}$ Slameto..Belajar dan Faktor-faktor yang Mempengarubinya. (Rineka Cipta, Jakarta:2003) 180

11 Winkel W. S. Psikologi Pengajaran, Cetakan II. (Gramedia, Jakarta: 1999), 188
} 
Berdasarkan pemeparan hakikat teori di atas dapat disimpulkan bahwa, minat merupakan kecenderungan seseorang terhadap obyek atau sesuatu kegiatan yang digemari yang disertai dengan perasaan senang, adanya perhatian, dan keaktifan berbuat. Minat belajar didefinisikan sebagai kecenderungan tingkah laku kesadaran seseorang dalam belajar yang diikuti perasaan senang dan menarik terhadap pelajaran yang diikutinya. Minat akan muncul dalam diri peserta didik apabila siswa tertarik terhadap kebutuhan yang sangat penting baginya atau merasa bahwa sesuatu tersebut merupakan hal yang harus dipelajari dan ketika ia sudah mempelajari maka akan timbul kebermaknaan dan berguna bagi dirinya.

Hasil belajar dalam pandangan Romiszowski di bagi menjadi empat ranah, yaitu; 1) kognitif; 2) psikomotorik; 3) reaksi emosional; dan 4) interaksi; yaitu keterampilan menerima dan menyampaikan informasi. ${ }^{2}$ Sementara Merrill and Twitcell mengklasifikasi hasil belajar dalam dua dimensi, yaitu; 1) tingkat unjuk kerja; 2) tipe isi.Dimensi unjuk kerja terdiri dari mengingat, menggunakan, dan menemukan.Sedangkan dimensi tipe isi pembelajaran dibedakan atas fakta, konsep, prinsip, dan prosedur. ${ }^{13}$ Kingsley membagi tiga macam hasil belajar, yaitu keterampilan dan kebiasaan; pengetahuan dan pengertian; sikap dan cita-cita. ${ }^{14}$ Masing-masing jenis belajar tersebut dapat diisi dengan bahan yang telah ditetapkan dalam kurikulum.

Menurut Gagne hasil belajar merupakan kapabilitas yang digolongkan atas: 1) informasi verbal; kemampuan menyatakan kembali informasi yang diperoleh dari proses belajar; 2) keterampilan intelek; melalui proses belajar seseorang akan mampu berfungsi dengan baik dalam masyarakat; 3) keterampilan motorik; kemampuan mengurai berbagai jenis keterampilan gerak; 4) sikap; kapabilitas yang mempengaruhi pilihan tentang tindakan mana yang akan dilakukan; dan 5) siasat kognitif; kapabilitas yang mengatur cara bagaimana peserta didik belajar mengelola belajarnya. ${ }^{15}$

Setiap mengikuti proses pembelajaran, peserta didik telah belajar mengenai informasi verbal atau pengetahuan verbal. Dalam belajar informasi verbal, orang menggunakan memorinya untuk mengingat berbagai macam informasi.Sementara keterampilan intelektual merupakan kemampuan untuk memberdayakan seseorang

\footnotetext{
12 A.J Romiszowski, Designing Instructional System Decision in Course Planning (New York: Nicholas Publishing Company, 1981), p: 253.

${ }^{13}$ David M. Merrill and David G Twitcell, Instructional Design Theory (New Jersey: Educational Technology Publication Englewood Cliffs, 1994), p: 106.

${ }^{14}$ Horward Kongsley, dalam Nana Sudjana, Op.Cit, p:22. 3.

${ }^{15}$ Robert M. Gagne, The Condition of Learning (New York: Hot Rinehart and Winston Inc, 1983), p:
} 
menjadi kompeten. Belajar tentang keterampilan intelektual berarti belajar bagaimana mengerjakan sesuatu dengan menggunakan proses intelektual. Sedangkan strategi kognitif adalah kapabilitas yang terorganisir secara internal yang menggerakkan individu untuk belajar, mengingat, dan berpikir.

Keterampilan motorik merupakan jenis keterampilan yang dimiliki seseorang yang diperoleh dengan proses latihan. Sedangkan sikap termasuk ranah afektif.Sikap tergantung pada kecenderungan bereaksi seseorang terhadap suatu situasi.Pengaruh yang ditimbulkan dari sikap berupa reaksi positif atau negatif yang tergantung pada situasi dan pandangan seseorang. ${ }^{16}$ Siasat atau strategi kognitif adalah kemampuan peserta didik untuk mengorganisasikan secara tepat cara-cara belajarnya, seperti strategi mengulang dan memahami informasi, strategi melakukan elaborasi sehingga rincian informasi lebih bermakna, strategi menyusun sehingga ide-ide dan istilah-istilah dapat dikelompokkan menjadi bagian-bagian yang lebih kecil, serta strategi untuk mengontrol dan memonitor pelaksanaan.

Hasil belajar dapam pandangan Gronlund dikelompokkan atas; (1) pengetahuan; (2) pemahaman; (3) keterampilan berpikir; (4) keterampilan dalam penampilan; (5) keterampilan berkomunikasi; (6) keterampilan berhitung; (7) keterampilan belajar sambil bekerja; (8) keterampilan bersosialisasi; (9) sikap; (10) minat; (11) apresiasi; dan (12) penyesuaian diri. ${ }^{17}$ Sedangkan Bloom membagi hasil belajar dalam tiga ranah, yaitu: (1) kognitif; berhubungan dengan perubahan pengetahuan; (2) afektif; berhubungan dengan perkembangan atau perubahan sikap sebagai hasil dari proses belajar, dan (3) psikomotorik; berhubungan dengan penguasaan keterampilan motorik. ${ }^{18}$ Dari pendapat Gagne, Gronlund, dan Bloom di atas menunjukkan bahwa mereka pada prinsipnya memiliki pandangan yang sama tentang hasil belajar. Gagne merinci hasil belajar atas lima bagian, di mana bagian-bagian tersebut masih termasuk dalam cakupan domain kognitif, afektif dan psikomotorik dari Bloom. Demikian pula dengan dua belas kategori hasil belajar menurut Gagne juga dapat dimasukkan dalam tiga domain, yaitu: (1) domain kognitif; meliputi: pengetahuan, pemahaman, dan keterampilan berpikir, (2) domain afektif; meliputi: sikap, minat, apresiasi, dan penyesuaian diri, dan (3) domain psikomotorik; meliputi keterampilan dalam penampilan, keterampilan berkomunikasi,

${ }^{16}$ Saifuddin Azwar, Sikap Manusia, Teori dan Pengukurannya (Yogyakarta: Pustaka Pelajar, 2007), p: 6

${ }^{17}$ Norman E. Gronlund, Stating Objective for Classroom Instruction (New York: Macmillan Publishing Co. Inc, 1978), p: 3.

${ }^{18}$ Benyamin S. Bloom, Taxonomy of Educational Objective (London: Longman, 1970), pp: 7-9. 
keterampilan berhitung, keterampilan belajar sambil bekerja, dan keterampilan dalam hubungan sosial.

Uraian di atas memberikan sebuah kesimpulan bahwa kemampuan yang diperoleh peserta didik melalui proses belajar mengajar di sekolah dalam kurun waktu tertentu yang meliputi domain kognitif, afektif, dan psikomotorik yang dinyatakan dengan angka dan diukur dengan menggunakan tes hasil belajar. Pembelajaran pendidikan agama Islam (PAI) merupakan upaya membelajarkan peserta didik supaya dapat belajar, butuh belajar, terdorong belajar, mau belajar dan tertarik untuk terus menerus mempelajari agama Islam, baik untuk kepentingan mengetahui bagaimana cara beragama yang benar maupun mempelajari Islam sebagai pengetahuan. ${ }^{19}$ Tujuan pendidikan agama Islam adalah "membentuk kepribadian muslim yaitu suatu kepribadian yang seluruh aspeknya dijiwai oleh ajaran Islam. ${ }^{20}$

\section{Metode Penelitian}

Penelitian ini dilakukan pada peserta didik SMAN 3 Probolinggo. penelitian bersifat verifikasi hipotesis menggunakan metode survei dengan pendekatan teknik korelasional. Bentuk konstelasi hubungan antar variabel dapat dilihat pada gambar 3.1.

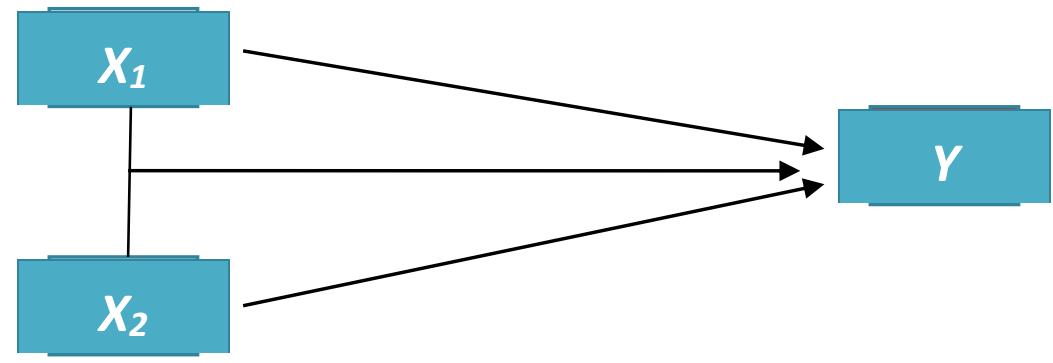

Gambar 3.1.

Bagan Konstelasi Korelasional antara $\mathrm{X}_{1}, \mathrm{X}_{2}$ dengan $\mathrm{Y}$

Keterangan :

$\mathrm{X}_{1}=$ Kecerdasan emosional

$\mathrm{X}_{2}=$ Minat Belajar

$\mathrm{Y}=$ Hasil belajar PAI

Populasi dalam penelitian ini adalah Peserta didik SMAN 3 Probolinggo . Teknik pengambilan sample menggunakan purporsif sampling. Yaitu menunjuk kelas XE sebanyak 30 Peserta didik dengan alasan kelas ini merupakan kelas unggulan. Analisis data dalam penelitian ini dilakukan dengan menggunakan statistik Regresi sederhana dan jamak, korelasi sederhana, parsial, dan jamak semua pengukuran dilakukan pada taraf signifikansi

\footnotetext{
${ }^{19}$ Muhaimin.Paradigma Pendidikan Islam (Upaya Mengefektifkan Pendidikan Agama Islam di Sekolab). (Bandung Remaja Rosdakarya, 2002).h 183

20Zuhairini, dkk.Metodologi Pendidikan Agama. (Jakarta: Ramadhani,1995) h159.
} 
$\alpha$ 0,05. Uji persyaratan analisis yang terdiri dari uji normalitas dan uji homogenitas dilakukan sebelum dilakukan pengujian hipotesis penelitian.

\section{Deskripsi Data Hasil Penelitian}

Penelitian ini terdiri dari tiga variabel, yaitu: hasil belajar PAI (Y), Kecerdasan Emosional $\left(\mathrm{X}_{1}\right)$, minat Belajar $\left(\mathrm{X}_{2}\right)$. Data yang diperoleh merupakan hasil perolehan jawaban dari kuesioner. Dalam proses kuantifikasi dilakukan dengan cara memberikan skor pada masing-masing butir soal dalam kuesioner yang telah disi responden. Selanjutnya data dianalisis menggunakan statistik deskriptif untuk menggambarkan nilai rata-rata, simpangan baku, median, modus, dan distribusi frekuensi yang disertai grafik dalam bentuk histogram. Berikut hasil statistik deskriptif dimulai dari Variabel $\mathrm{X}_{1}$, variabel $\mathrm{X}_{2}$ dan variabel $\mathrm{Y}$.

\section{a. Kecerdasan Emosional $\left(\mathrm{X}_{1}\right)$}

Hasil analisis data 30 siswa kelas XE SMAN 3 Probolinggo Probolinggo tentang Kecerdasan Emosional menunjukkan bahwa rentangan skor teoretik Kecerdasan Emosional dari 25 sampai 100, sedangkan rentangan empirik dari 71 sampai dengan 89 Harga rerata (mean) sebesar 79,13; simpangan baku (standar deviasi) sebesar 5,8; median sebesar 79,5; modus sebesar 72. Dengan menggunakan aturan Strugess, maka distribusi frekuensi skor Kecerdasan Emosional dapat digambarkan pada tabel 4.1.

Tabel 4.1

Daftar Distribusi Frekuensi Kecerdasan Emosional (X1)

\begin{tabular}{|c|c|c|c|c|}
\hline No & $\begin{array}{c}\text { Kelas } \\
\text { Interval }\end{array}$ & $\begin{array}{c}\text { Frekuensi } \\
\text { Absolut }\end{array}$ & $\begin{array}{c}\text { Frekuensi relatif } \\
(\mathbf{\%})\end{array}$ & $\begin{array}{c}\text { Frekuensi Kumulatif } \\
(\mathbf{\%})\end{array}$ \\
\hline 1 & $71-73$ & 8 & 26.7 & 26.7 \\
\hline 2 & $74-76$ & 4 & 13.3 & 40.0 \\
\hline 3 & $77-79$ & 3 & 10.0 & 50.0 \\
\hline 4 & $80-82$ & 6 & 20.0 & 70.0 \\
\hline 5 & $83-85$ & 4 & 13.3 & 83.3 \\
\hline 6 & $86-88$ & 3 & 10.0 & 93.3 \\
\hline 7 & $89-91$ & 2 & 6.7 & 100.0 \\
\hline & Jumlah & 30 & 100,00 & \\
\hline
\end{tabular}

Berdasarkan tabel 4.1 menunjukkan nilai skor dengan frekuensi atau jumlah responden terbanyak berkisar antara 50 dan 53 pada kelas interval pertama sebanyak 8 atau 26,7\%. Kedua berkisar antara 80 dan 82 kelas interval keempat sebanyak 6 atau $20 \%$. Jika perolehan kedua kelas tersebut di jumlah akan diperoleh angka 14 atau 46,7 \%. Secara visual distribusi frekuensi skor Kecerdasan Emosional diganbarkan bentuk histogram seperti pada gambar 4.1. 


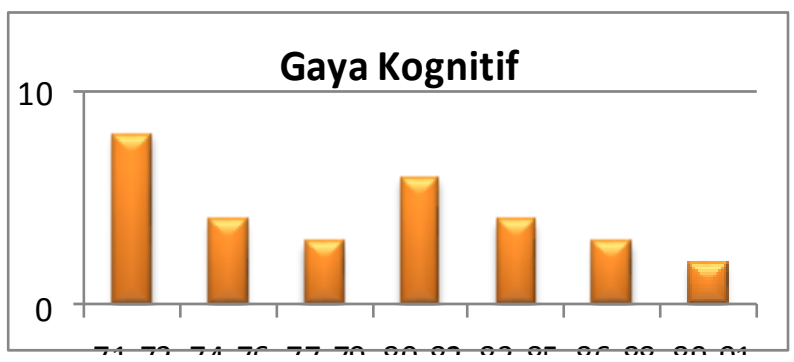

Gambar 4.1. Histogram Distribusi Skor Kecerdasan Emosional Siswa

\section{b. Minat Belajar $\left(\mathrm{X}_{2}\right)$}

Hasil analisis data 30 siswa kelas X E SMAN 3 Probolinggo tentang minat Belajar menunjukkan bahwa rentangan skor teoretik minat Belajar dari 25 sampai 100, sedangkan rentangan empirik dari 57 sampai dengan 90 Harga rerata (mean) sebesar 74,83; simpangan baku (standar deviasi) sebesar 8,6; median sebesar 76,5; modus sebesar 77. Variabel ini diperoleh jumlah kelas interval 6 dan panjang interval 6, dan distribusi frekuensi di sajikan pada tabel seperti pada tabel 4.2.

Tabel 4.2

Hasil distribusi Frekuensi Minat Belajar

\begin{tabular}{|c|c|c|c|c|}
\hline No & Nilai & $\begin{array}{c}\text { Frekuensi } \\
\text { Absolut }\end{array}$ & $\begin{array}{c}\text { Frekuensi } \\
\text { relatif (\%) }\end{array}$ & $\begin{array}{c}\text { Frekuensi } \\
\text { Kumulatif (\%) }\end{array}$ \\
\hline 1 & $57-62$ & 2 & 6.7 & 6.7 \\
\hline 2 & $63-68$ & 6 & 20.0 & 26.7 \\
\hline 3 & $69-74$ & 6 & 20.0 & 46.7 \\
\hline 4 & $75-80$ & 7 & 23.3 & 70.0 \\
\hline 5 & $81-86$ & 8 & 26.7 & 96.7 \\
\hline 6 & $87-92$ & 1 & 3.3 & 100.0 \\
\hline & & 30 & $100 \%$ & \\
\hline
\end{tabular}

Berdasarkan tabel 4.2 menunjukkan jumlah responden terbanyak berkisar antara 81dan 86 pada kelas interval kelima sebanyak 8 atau 26,7 \%. Sedangkan k jumlah responden terbanyak kedua adalah berkisar antara 75 dan 80 yaitu kelas interval keempat sebanyak 7 atau 23,3\%. Gambaran skor minat Belajar ditampilkan dalam bentuk histogram pada gambar 4.2.

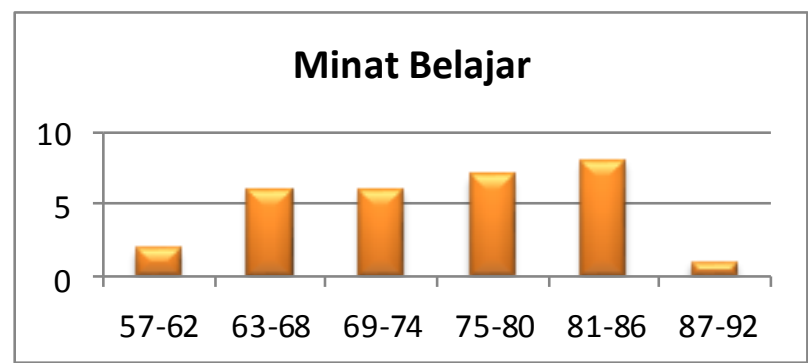

Gambar 4.2. Histogram Distribusi Skor minat Belajar Siswa 


\section{c. Hasil Belajar (Y)}

Hasil analisis data 30 siswa kelas X E SMAN 3 Probolinggo tentang hasil belajar PAI menunjukkan bahwa rentangan skor teoretik hasil belajar PAI dari 0 sampai 100, sedangkan rentangan empirik dari 76 sampai dengan 99 Harga rerata (mean) sebesar 89,57; simpangan baku (standar deviasi) sebesar 5,8; median sebesar 90,00; modus sebesar 90. Pada variabel ini diperoleh jumlah kelas interval 6 dan panjang interval 4. Distribusi frekuensi skor hasil belajar PAI di tampilakan pada tabel 4.3.

Tabel 4.3

Distribusi Frekuensi Hasil belajar PAI

\begin{tabular}{|c|c|c|c|c|}
\hline No & Nilai & $\begin{array}{c}\text { Frekuensi } \\
\text { Absolut }\end{array}$ & $\begin{array}{c}\text { Frekuensi } \\
\text { relatif (\%) }\end{array}$ & $\begin{array}{c}\text { Frekuensi } \\
\text { Kumulatif (\%) }\end{array}$ \\
\hline 1 & $76-79$ & 2 & 6.7 & 6.7 \\
\hline 2 & $80-83$ & 3 & 10.0 & 16.7 \\
\hline 3 & $84-87$ & 3 & 10.0 & 26.7 \\
\hline 4 & $88-91$ & 9 & 30.0 & 56.7 \\
\hline 5 & $92-95$ & 8 & 26.6 & 83.3 \\
\hline 6 & $96-99$ & 5 & 16.7 & 100.0 \\
\hline & & 30 & 100,00 & \\
\hline
\end{tabular}

Data skor di atas diperoleh berdasarkan test hasil belajar PAI. Berdasarkan perolehan data menunjukkan nilai skor hasil belajar PAI dengan frekuensi responden terbanyak adalah antara 88 dan 91 yaitu kelas interval keempat sebanyak 9 atau $30 \%$. frekuensi responden terbanyak kedua antara 92 dan 95 yaitu kelas interval kelima sebanyak 8 atau 26,6 \%. Distribusi frekuensi skor hasil belajar PAI dalam bentuk histogram seperti seperti pada gambar 4.3.

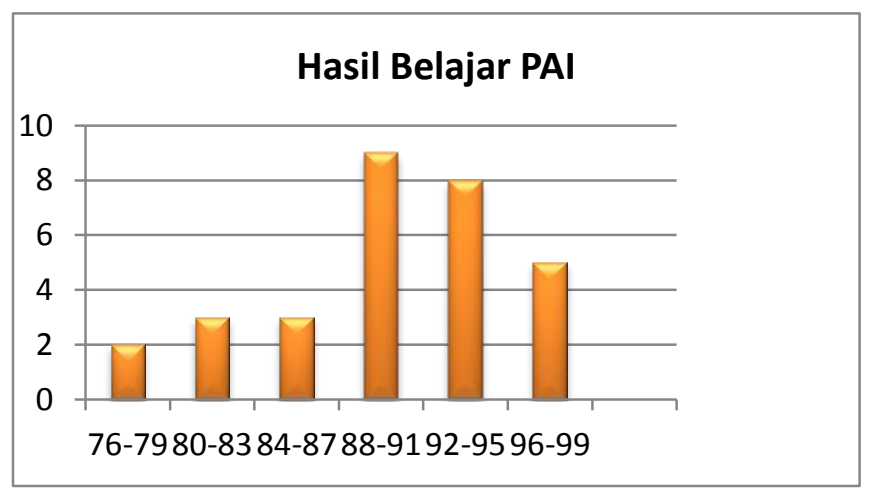

Gambar 4.3. Histogram Distribusi Skor Hasil belajar PAI Siswa kelas X E 


\section{Pengujian Persyaratan Analisis}

\section{Uji Normalitas}

Uji normalitas bertujuan untuk mengetahui normal atau tidaknya suatu distribusi data. Uji normalitas ini membandingkan antara hasil perolehan data Kecerdasan Emosional (X1), Minat Belajar (X2) dan Hasil belajar PAI (Y) dengan data berdistribusi normal yang memiliki mean dan strandar deviasi yang sama dengan hasil perolehan data. Untuk melakukan uji normalitas dengan menggunakan uji kolmogorof-Smirnov. selanjutnya secara keseluruhan hasil perhitungan tersebut dapat dilihat pada rangkuman tabel 4.4.

Tabel 4.4

Uji Normalitas

One-Sample Kolmogorov-Smirnov Test

\begin{tabular}{|c|c|c|c|c|}
\hline & & $E Q$ & Minat Belajar & Prestasi PAI \\
\hline$N$ & & 30 & 30 & 30 \\
\hline \multirow[t]{2}{*}{ Normal Parameters ${ }^{a, b}$} & Mean & 79.13 & 74.83 & 89.57 \\
\hline & Std. Deviation & 5.835 & 8.619 & 5.847 \\
\hline \multirow[t]{3}{*}{ Most Extreme Differences } & Absolute & .120 & .099 & .130 \\
\hline & Positive & .120 & .064 & .069 \\
\hline & Negative & -.092 & -.099 & -.130 \\
\hline Kolmogorov-Smirnov Z & & .658 & .544 & .710 \\
\hline Asymp. Sig. (2-tailed) & & .780 & .929 & .695 \\
\hline
\end{tabular}

a. Test distribution is Normal.

b. Calculated from data.

Berdasarkan Uji normalitas di atas maka angka signifikansi uji asymp.Sig atau $\boldsymbol{P}$. value $>0,05$ atau 0,695>0,05 (hasil belajar PAI), 0,929>0,05 (hasil Kecerdasan Emosional) dan 0,78>0,05 (Minat Belajar) maka data menujukkan berdistribusi normal.

\section{Uji Linieritas}

Uji linieritas pertama adalah variabel Kecerdasan Emosional $\left(\mathrm{X}_{1}\right)$ terhadap hasil belajar (Y).Hasil perhitungan keberartian dan linieritas tertera pada tabel 4.5:

\section{Tabel 4.5}

\begin{tabular}{|c|c|c|c|c|c|c|c|}
\hline & & & $\begin{array}{l}\text { Sum of } \\
\text { Squares }\end{array}$ & df & Mean Square & $\mathrm{F}$ & Sig. \\
\hline \multirow[t]{5}{*}{ Prestasi PAl ${ }^{*} E Q$} & Between Groups & (Combined) & 454.200 & 15 & 30.280 & .789 & .673 \\
\hline & & Linearity & 72.050 & 1 & 72.050 & 1.878 & .192 \\
\hline & & Deviation from Linearity & 382.150 & 14 & 27.296 & .711 & .734 \\
\hline & Within Groups & & 537.167 & 14 & 38.369 & & \\
\hline & Total & & 991.367 & 29 & & & \\
\hline
\end{tabular}


Berdasarkan hasil pengujian pada tabel 4.5 dapat diinterpretasikan sig. dari Deviation from linierity adalah $\mathbf{0 , 7 3 4}$. Artinya ini lebih besar dari pada $0,05(\mathbf{0 , 7 3 4 > 0 , 0 5 )}$. Dengan demikian dapat disimpulkan bahwa hubungan antara Variabel Y dan Variabel $\mathrm{X} 1$ adalah linier. Uji linieritas yang kedua adalah minat Belajar $\left(\mathrm{X}_{2}\right)$ terhadap hasil belajar (Y). Hasil perhitungan keberartian dan linieritas tertera pada tabel 4.6:

Tabel 4.6

\begin{tabular}{|c|c|c|c|c|c|c|c|}
\hline \multicolumn{8}{|c|}{ ANOVA Table } \\
\hline & & & $\begin{array}{l}\text { Sum of } \\
\text { Squares }\end{array}$ & df & Mean Square & $\mathrm{F}$ & Sig. \\
\hline \multirow{5}{*}{$\begin{array}{l}\text { Prestasi PA| }{ }^{*} \text { Winat } \\
\text { Belajar }\end{array}$} & \multirow[t]{3}{*}{ Between Groups } & (Combined) & 650.033 & 19 & 34.212 & 1.002 & .521 \\
\hline & & Linearity & 40.171 & 1 & 40.171 & 1.177 & .303 \\
\hline & & Deviation from Linearity & 609.863 & 18 & 33.881 & .993 & .527 \\
\hline & \multicolumn{2}{|l|}{ Within Groups } & 341.333 & 10 & 34.133 & & \\
\hline & \multicolumn{2}{|l|}{ Total } & 991.367 & 29 & & & \\
\hline
\end{tabular}

Berdasarkan hasil pengujian pada tabel 4.5 dapat diinterpretasikan sig. dari Deviation from linierity adalah 0,527. Artinya ini lebih besar dari pada 0,05 $(\mathbf{0 , 5 2 7}>\mathbf{0 , 0 5})$. Dengan demikian dapat disimpulkan bahwa hubungan antara Variabel Y dan Variabel X2 adalah linier. Uji linieritas yang ketiga adalah regresi ganda secara bersama-sama antara variabel Kecerdasan Emosional $\left(\mathrm{X}_{1}\right)$ dan minat Belajar $\left(\mathrm{X}_{2}\right)$ terhadap hasil belajar $(Y)$. Selanjutnya dilakukan uji linieritas dan keberartian persamaan regresi menggunakan Uji multikorelasi (gejala multikollinieritas). Hasil perhitunganUji multikorelasi tertera pada tabel 4.7: Hasil perhitungan keberartian dan linieritas tertera pada tabel 4.7

Tabel 4.7

\begin{tabular}{|c|c|c|c|c|c|c|c|c|c|c|c|}
\hline \multirow[b]{2}{*}{ Mode } & & \multicolumn{2}{|c|}{ Unstandardized Coefincicints } & \multirow{2}{*}{$\begin{array}{l}\text { Standardiced } \\
\text { Coeficientis } \\
\text { Betata }\end{array}$} & \multirow[b]{2}{*}{1} & \multirow[b]{2}{*}{ Sig. } & \multicolumn{3}{|c|}{ Corredtions } & \multicolumn{2}{|c|}{ Collinearity Statistics } \\
\hline & & $B$ & Stot. Error & & & & Zero-order & Patilal & Pat & Tolerance & $V F$ \\
\hline \multirow[t]{3}{*}{1} & (Constant) & 75.695 & 14.458 & & 5.235 & .000 & & & & & \\
\hline & EO & .398 & .188 & 397 & 2.117 & .044 & .270 & 377 & .370 & .865 & 1.157 \\
\hline & Ninat Belajar & .236 & .127 & .348 & .1851 & .075 & .201 & .330 & .323 & .865 & 1.157 \\
\hline
\end{tabular}

Berdasarkan hasil pengujian pada tabel 4.5 dapat diinterpretasikan Nilai VIF=1,157. Artinya nilai VI F ini lebih kecil daripada $10 \quad(\mathbf{1 , 1 5 7}<\mathbf{1 0})$. Dengan demikian tidak terjadi multikolinieritas diantara variabel bebas. Dengan demikian dapat disimpulkan bahwa hubungan antara Variabel Y dan Variabel X1, X2 adalah linier. 
Selanjutnya dari persamaan regresi ganda tersebut dapat diinterpretasikan bahwa apabila dilihat secara bersama-sama hubungan Kecerdasan Emosional dan minat Belajar dengan hasil belajar diukur dengan instrumen yang digunakan dalam penelitian ini, maka setiap kenaikan skor akan diikuti dengan kenaikan skor hasil belajar.

\section{Pengujian Hipotesis}

\section{Hubungan antara Kecerdasan Emosional dengan Hasil Belajar}

Hipotesis pertama penelitian ini adalah terdapat hubungan positif antara Kecerdasan Emosional dengan hasil belajar. Pengujian hipotesis pertama dilakukan dengan menggunakan rumus korelasi Pearson Product Moment. Berdasarkan hasil perhitungan diperoleh koefisien korelasi antara Kecerdasan Emosional $\left(\mathrm{X}_{1}\right)$ dengan hasil belajar $(\mathrm{Y}), \mathrm{r}_{\mathrm{y} 1}=0,27$. Angka ini mengisyaratkan bahwa hubungan antara Kecerdasan Emosional dengan hasil belajar adalah negatif. Hasil perhitungan pengujian keberartian koefisien korelasi dengan menggunakan SPSS 21 tersebut tertera pada tabel pada tabel 4.8

Tabel 4.8

Hasil Pengujian Keberartian Korelasi antara $\mathrm{X}_{1}$ dengan $\mathrm{Y}$

\begin{tabular}{|ll|r|r|}
\hline \multicolumn{2}{|c|}{ Correlations } \\
\hline & & Prestasi PAI & $\begin{array}{r}\text { Kecerdasan } \\
\text { Emosional }\end{array}$ \\
\hline Pearson Correlation & Prestasi PAl & 1.000 & .270 \\
& Kecerdasan Emosional & .270 & 1.000 \\
\hline Sig. (1-tailed) & Prestasi PAl &. & .075 \\
& Kecerdasan Emosional & .075 &. \\
\hline N & Prestasi PAl & 30 & 30 \\
& Kecerdasan Emosional & 30 & 30 \\
\hline
\end{tabular}

Model Summary

\begin{tabular}{|l|l|r|r|r|}
\hline Model & $\mathrm{R}$ & R Square & $\begin{array}{c}\text { Adjusted R } \\
\text { Square }\end{array}$ & $\begin{array}{c}\text { Std. Error of } \\
\text { the Estimate }\end{array}$ \\
\hline 1 & $.270^{\mathrm{a}}$ & .073 & .040 & 5.730 \\
\hline
\end{tabular}

a. Predictors: (Constant), Kecerdasan Emosional

b. Dependent Variable: Prestasi PAI

\begin{tabular}{|c|c|c|c|c|c|c|}
\hline \multicolumn{7}{|c|}{ ANOVA $^{a}$} \\
\hline \multicolumn{2}{|c|}{ Model } & $\begin{array}{l}\text { Sum of } \\
\text { Squares }\end{array}$ & df & Mean Square & $\mathrm{F}$ & Sig. \\
\hline \multirow[t]{3}{*}{1} & Regression & 72.050 & 1 & 72.050 & 2.194 & $.150^{\mathrm{b}}$ \\
\hline & Residual & 919.317 & 28 & 32.833 & & \\
\hline & Total & 991.367 & 29 & & & \\
\hline
\end{tabular}

a. Dependent Variable: Prestasi PAl

b. Predictors: (Constant), Kecerdasan Emosional

Dari tabel korelasi di atas dapat diketahui bahwa nilai $\mathrm{r}$ hitung adalah 0,27. Angka ini menunjukkan korelasi yang rendah. Antara variabel X dan Variabel Y. Sig (1 
tailed ) menunjukkan hubungan yang tidak signifikan karena 0,075>0,05 dimana 0,05 adalah taraf signifikan. $\mathrm{R}$ square merupakan koefisien determinasi. Artinya besarnya pengaruh Variabel $\mathrm{X}_{1}$ terhadap $\mathrm{Y}$ adalah sebesar 7,3 \% dan besarnya variabel lain yang mempengaruhi variabel $\mathrm{Y}$ adalah 92,7. Jika nilai probabilitas lebih kecil daripada atau sama dengan nilai probabilitas sig $(0,05 \leq 0,07)$, Ho Diterima (Ha Ditolak) artinya tidak signifikan. Dengan demikian variabel X1 tidak berpengaruh secara signifikan terhadap variabel Y. Hasil yang tidak signifikan bisa dipengaruhi dari hasil belajar PAI yang diambil dari data Ujian Tengah Semester. Dimana penilaiannya belum diuji validitasnya pada jenis soal yang digunakan maupun sistem penilaiannya.

\section{a. Hubungan antara Minat Belajar dengan Hasil Belajar}

Hipotesis kedua penelitian ini adalah terdapat hubungan positif antara variabel $\left(\mathrm{X}_{2}\right)$ dengan $(\mathrm{Y})$. Hasil perhitungan diperoleh koefisien korelasi antara minat belajar $\left(\mathrm{X}_{2}\right)$ dengan hasil belajar $(\mathrm{Y}), \mathrm{r}_{\mathrm{y} 2}=-0,27$. Perolehan ini mengisyaratkan bahwa $\mathrm{X}_{2}$ ) dengan $(\mathrm{Y})$ adalah negatif. Hasil perolehan pengujian keberartian koefisien korelasi dengan menggunakan SPSS 21 tersebut tertera pada tabel pada tabel 4.9

Tabel 4.9

Hasil Pengujian Keberartian Korelasi antara $\mathrm{X}_{2}$ dengan $\mathrm{Y}$

\begin{tabular}{|c|c|c|c|c|c|}
\hline \multicolumn{6}{|c|}{ Correlations } \\
\hline & & & & Prestasi PAI & Minat Belajar \\
\hline \multirow{2}{*}{\multicolumn{2}{|c|}{ Pearson Correlation }} & \multirow{2}{*}{\multicolumn{2}{|c|}{$\begin{array}{l}\text { Prestasi PAI } \\
\text { Minat Belajar }\end{array}$}} & 1.000 & -.201 \\
\hline & & & & -.201 & 1.000 \\
\hline \multirow{2}{*}{\multicolumn{2}{|c|}{ Sig. (1-tailed) }} & \multirow{2}{*}{\multicolumn{2}{|c|}{$\begin{array}{l}\text { Prestasi PAI } \\
\text { Minat Belajar }\end{array}$}} & & .143 \\
\hline & & & & .143 & . \\
\hline \multirow{2}{*}{\multicolumn{2}{|c|}{$N$}} & \multirow{2}{*}{\multicolumn{2}{|c|}{$\begin{array}{l}\text { Prestasi PAI } \\
\text { Minat Belajar }\end{array}$}} & 30 & 30 \\
\hline & & & & 30 & 30 \\
\hline \multicolumn{6}{|c|}{ Model Summary } \\
\hline Model & $\mathrm{R}$ & R Square & & $\begin{array}{l}\text { ljusted R } \\
\text { Square }\end{array}$ & $\begin{array}{l}\text { Std. Error of } \\
\text { the Estimate }\end{array}$ \\
\hline 1 & $201^{\mathrm{a}}$ & .041 & & .006 & 5.828 \\
\hline
\end{tabular}

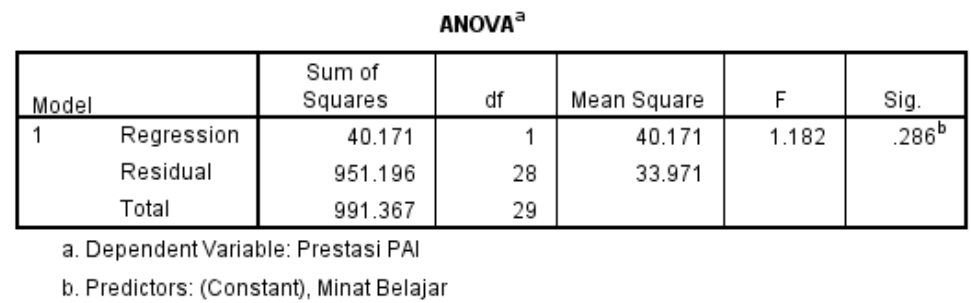

Dari tabel korelasi di atas dapat diketahui bahwa nilai $\mathrm{r}$ hitung adalah -0,27. Angka ini menunjukkan korelasi yang sangat rendah bahkan minus. Antara variabel 
$\mathrm{X}$ dan Variabel Y. Sig (1 tailed ) menunjukkan hubungan yang tidak signifikan karena $0,143>0,05$ dimana 0,05 adalah taraf signifikan. $\mathrm{R}$ square merupakan koefisien determinasi. Artinya besarnya pengaruh Variabel $\mathrm{X}_{2}$ terhadap $\mathrm{Y}$ adalah sebesar 4,1 \% dan besarnya variabel lain yang mempengaruhi variabel $\mathrm{Y}$ adalah 95,9. Jika nilai probabilitas lebih kecil daripada atau sama dengan nilai probabilitas sig $(0,05 \leq 0,041)$, Ho Diterima (Ha Ditolak) artinya tidak signifikan. Dengan demikian variabel $\mathrm{X}_{2}$ tidak berpengaruh secara signifikan terhadap variabel $\mathrm{Y}$. Hasil yang tidak signifikan bisa dipengaruhi dari hasil belajar PAI yang diambil dari data Ujian Tengah Semester, dimana penilaiannya belum diuji validitasnya pada jenis soal yang digunakan maupun sistem penilaiannya.

\section{b. Hubungan antara Kecerdasan Emosional dan minat Belajar secara bersama-} sama dengan Hasil Belajar

Hipotesis ketiga penelitian ini adalah terdapat hubungan positif secara bersama-sama antara Kecerdasan Emosionaldan minat Belajar dengan hasil belajar. Pengujian hipotesis ketiga dilakukan dengan hasil analisis multivariate dengan regresi ganda. Hasil statistik diketahui nilai korelasi $r$ hitung sebesar $r_{\mathrm{y} 3}=0,421$. Angka ini mengisyaratkan bahwa hubungan secara bersama-sama antara Kecerdasan Emosional dan minat Belajar dengan hasil belajar adalah positif.Hasil perhitungan pengujian keberartian koefisien korelasi dengan menggunakan SPSS 21 tersebut tertera pada tabel 4.10 .

Tabel 4.10

\section{Hasil Pengujian Keberartian Korelasi antara $X_{1} X_{2}$ dengan $Y$}

Model Summary

\begin{tabular}{|l|l|r|r|r|}
\hline Model & R & R Square & $\begin{array}{c}\text { Adjusted R } \\
\text { Square }\end{array}$ & $\begin{array}{c}\text { Std. Error of } \\
\text { the Estimate }\end{array}$ \\
\hline 1 & $.421^{\mathrm{a}}$ & .177 & .116 & 5.497 \\
\hline
\end{tabular}

a. Predictors: (Constant), Kecerdasan Emosional, Minat Belajar

b. Dependent Variable: Prestasi PAI

Tabel 4.11

ANOVA ${ }^{a}$

\begin{tabular}{|ll|r|r|r|r|c|}
\hline Model & & \multicolumn{1}{c|}{$\begin{array}{c}\text { Sum of } \\
\text { Squares }\end{array}$} & df & Mean Square & F & Sig. \\
\hline 1 & Regression & 175.586 & 2 & 87.793 & 2.906 & $.072^{\mathrm{b}}$ \\
& Residual & 815.781 & 27 & 30.214 & & \\
& Total & 991.367 & 29 & & & \\
\hline
\end{tabular}

a. Dependent Variable: Prestasi PAI

b. Predictors: (Constant), Kecerdasan Emosional, Minat Belajar 
Uji signifikansi koefisien korelasi diperoleh dari tabel Model Summary. Terlihat pada baris pertama koefisien korelasi $=0,421$ dan $\mathrm{F}_{\text {hitung }}\left(\mathrm{F}_{\text {change }}\right)=2,906$ dengan p-value $=0,072>0,05$. Hal ini berarti $\mathrm{H}_{0}$ ditolak. $\boldsymbol{R}$ Square merupakan koefisien Determinasi.Besarnya $\mathrm{R}$ Square adalah $\left(\mathrm{R}^{2}\right)$ adalah $0,177=17 \%$. Artinya besarnya pengaruh Kecerdasan Emosional dan minat Belajar terhadap hasil belajar PAI $17 \%$ dan besarnya variabel lain yang mempengaruhi variabel hasil belajar PAI adalah $83 \%$.

Nilai $\mathrm{R}$ square sebesar 0,17 menunjukkan bahwa variabel Kecerdasan Emosional dan minat Belajar berkontibusi terhadap Hasil belajar PAI sebesar 17\%, sedangkan sisanya sebesar $83 \%$ dijelaskan oleh faktor lain yang tidak dianalisis dalam penelitian ini.

\section{Interpretasi Hasil Penelitian}

Penelitian ini mendiskripsikan dan menguji hubungan dari variabel terikat yaitu Kecerdasan Emosional dan minat Belajar terhadap hasil belajar PAI.Teknik analisis yang digunakan adalah korelasi dan regresi ganda.Uji prasyarat yang harus dilakukan yaitu uji normalitas dengan menggunakan Uji kolmogorof-smirnov dan uji linieritas.Ketentuan dalam uji galat adalah bila asymp.Sig atau $\boldsymbol{P}$. value $>0,05$, menujukkan data berdistribusi normal. Akan tetapi jika asymp.Sig atau $\boldsymbol{P}$. value $<0,05$ menunjukkan data tidak berdistribusi normal. Berdasarkan Uji normalitas maka angka signifikansi uji asymp.Sig atau $\boldsymbol{P}$ value $>0,05$ atau 0,695 >0,05 (hasil belajar PAI), 0,929>0,05 (hasil Kecerdasan Emosional) dan 0,78>0,05 (Minat Belajar) maka data menujukkan berdistribusi normal.

Uji selanjutnya adalah Uji linieritas untuk mengetahui hubungan antara variebel bebas dan terikat linier atau tidak.Pengujian dilakukan dengan bantuan SPSS 21 for Windows.Criteria pengujian linieritas adalah jika nilai signifikansi Deviation From Linierity lebih besar 0,05 maka hubungan antara variabel bebas dan terikat adalah linier. Uji linieritas pertama adalah variabel Kecerdasan Emosional $\left(\mathrm{X}_{1}\right)$ terhadap hasil belajar $(\mathrm{Y})$.

Berdasarkan hasil pengujian dapat diinterpretasikan sig. dariDeviation from linierity

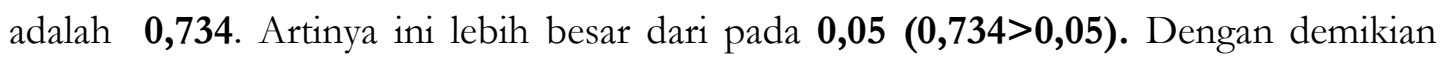
dapat disimpulkan bahwa hubungan antara Variabel Y dan Variabel X1 adalah linier. Hasil pengujian Variabel Y dan Variabel X2 dapat diinterpretasikan sig. dari Deviation from linierityadalah 0,527. Artinya ini lebih besar dari pada 0,05 (0,527>0,05). Dengan demikian dapat disimpulkan bahwa hubungan antara Variabel Y dan Variabel X2 adalah 
linier. Uji linieritas yang ketiga adalah regresi ganda secara bersama-sama antara variabel Kecerdasan Emosional $\left(\mathrm{X}_{1}\right)$ dan minat Belajar $\left(\mathrm{X}_{2}\right)$ terhadap hasil belajar $(\mathrm{Y})$. Selanjutnya dilakukan uji linieritas dan keberartian persamaan regresi menggunakan Uji multikorelasi (gejala multikollinieritas).

Hasil pengujian dapat diinterpretasikan Nilai VIF=1,157. Artinya nilai VI F ini lebih kecil daripada $10 \quad(\mathbf{1 , 1 5 7 < 1 0 )}$. Dengan demikian tidak terjadi multikolinieritas diantara variabel bebas.Dengan demikian dapat disimpulkan bahwa hubungan antara Variabel Y dan Variabel X1, X2 adalah linier.

Selanjutnya dari persamaan regresi ganda tersebut dapat diinterpretasikan bahwa apabila dilihat secara bersama-sama hubungan Kecerdasan Emosional dan minat Belajar dengan hasil belajar diukur dengan instrumen yang digunakan dalam penelitian ini, maka setiap kenaikan skor akan diikuti dengan kenaikan skor hasil belajar.

Penelitian ini bertujuan untuk mengetahui dan menganalisis hubungan Kecerdasan Emosional dan minat Belajar dengan hasil belajar PAI Siswa kelas X E SMAN 3 Probolinggo. Hasil belajar adalah kemampuan yang diperoleh peserta didik melalui proses belajar mengajar di sekolah dalam kurun waktu tertentu yang meliputi domain kognitif, afektif, dan psikomotorik yang dinyatakan dengan angka dan diukur dengan menggunakan tes hasil belajar. Hasil belajar yang dimiliki siswa menurut Gagne dipengaruhi oleh 3 tiga domain, yaitu: (1) domain kognitif; meliputi: pengetahuan, pemahaman, dan keterampilan berpikir, (2) domain afektif; meliputi: sikap, minat, apresiasi, dan penyesuaian diri, dan (3) domain psikomotorik; meliputi keterampilan dalam penampilan, keterampilan berkomunikasi, keterampilan berhitung, keterampilan belajar sambil bekerja, dan keterampilan dalam hubungan social. Pada penelitian ini akan menggali variabel Kecerdasan Emosional dan minat Belajar yang berhubungan dengan Hasil belajar.

Penelitian ini mengajukan tiga hipotesis yang perlu diuji secara empiris. Semua hipotesis adalah dugaan tentang hubungan antara Kecerdasan Emosional, minat belajar, baik secara sendiri-sendiri maupun secara bersama-sama dengan hasil belajar PAI.

Hipotesis pertama penelitian ini adalah terdapat hubungan positif antara Kecerdasan Emosional dengan hasil belajar. Pengujian hipotesis pertama dilakukan dengan menggunakan rumus korelasi Pearson Product Moment. Berdasarkan hasil perhitungan diperoleh koefisien korelasi antara Kecerdasan Emosional $\left(\mathrm{X}_{1}\right)$ dengan hasil belajar $(\mathrm{Y}), \mathrm{r}_{\mathrm{y} 1}=0,27$. Angka ini mengisyaratkan bahwa hubungan antara Kecerdasan Emosional dengan hasil belajar adalah negatif.Dari tabel korelasi dapat diketahui bahwa nilai $r$ hitung adalah 0,27 . Angka ini menunjukkan korelasi yang rendah. Antara variabel 
$\mathrm{X}$ dan Variabel Y. Sig (1 tailed ) menunjukkan hubungan yang tidak signifikan karena 0 , 075>0,05 dimana 0,05 adalah taraf signifikan. $\mathrm{R}$ square merupakan koefisien determinasi. Artinya besarnya pengaruh Variabel $\mathrm{X}_{1}$ terhadap $\mathrm{Y}$ adalah sebesar 7,3\% dan besarnya variabel lain yang mempengaruhi variabel $\mathrm{Y}$ adalah 92,7. Jika nilai probabilitas lebih kecil daripada atau sama dengan nilai probabilitas sig $(0,05 \leq 0,07)$, Ho Diterima (Ha Ditolak) artinya tidak signifikan. Dengan demikian variabel X1 tidak berpengaruh secra signifikan terhadap variabel Y.

Hipotesis kedua terdapat hubungan positif antara minat Belajar dengan hasil belajar. Berdasarkan hasil perhitungan diperoleh koefisien korelasi antara minat belajar $\left(\mathrm{X}_{2}\right)$ dengan hasil belajar $(\mathrm{Y}), \mathrm{r}_{\mathrm{y} 2}=-0,27$. Angka ini menunjukkan korelasi yang sangat rendah bahkan minus. Antara variabel X dan Variabel Y. Sig (1 tailed ) menunjukkan hubungan yang tidak signifikan karena $0,143>0,05$ dimana 0,05 adalah taraf signifikan. $\mathrm{R}$ square merupakan koefisien determinasi. Artinya besarnya pengaruh Variabel $\mathrm{X}_{2}$ terhadap $\mathrm{Y}$ adalah sebesar 4,1 \% dan besarnya variabel lain yang mempengaruhi variabel Y adalah 95,9. Jika nilai probabilitas lebih kecil daripada atau sama dengan nilai probabilitas sig $(0,05 \leq 0,041)$, Ho Diterima (Ha Ditolak) artinya tidak signifikan. Dengan demikian variabel $\mathrm{X}_{2}$ tidak berpengaruh secara signifikan terhadap variabel $\mathrm{Y}$.

Hipotesis ketiga penelitian ini adalah terdapat hubungan positif secara bersamasama antara Kecerdasan Emosional dan minat Belajar dengan hasil belajar. Pengujian hipotesis ketiga dilakukan dengan hasil analisis multivariate dengan regresi ganda Kecerdasan Emosional dan minat Belajar dengan hasil belajar PAI. Hasil statistik diketahui nilai korelasi $r$ hitung sebesar $r_{y 3}=0,421$. Angka ini mengisyaratkan bahwa hubungan secara bersama-sama antara Kecerdasan Emosional dan minat Belajar dengan hasil belajar adalah positif.

Selanjutnya uji signifikansi koefisien korelasi diperoleh dari tabel Model Summary yang terdapat pada baris pertama koefisien korelasi $=0,421$ dan $F_{\text {hitung }}\left(F_{\text {change }}\right)=2,906$ dengan p-value $=0,072>0,05$. Hal ini berarti $\mathrm{H}_{0}$ ditolak. $\boldsymbol{R}$ Square merupakan koefisien Determinasi.Besarnya $\mathrm{R}$ Square adalah $\left(\mathrm{R}^{2}\right)$ adalah $0,177=17 \%$. Artinya besarnya pengaruh Kecerdasan Emosional dan minat Belajar terhadap hasil belajar PAI $17 \%$ dan besarnya variabel lain yang mempengaruhi variabel hasil belajar PAI adalah $83 \%$.

Nilai R square sebesar 0,17 menunjukkan bahwa variabel Kecerdasan Emosional dan minat Belajar berkontibusi terhadap Hasil belajar PAI sebesar 17\%, sedangkan sisanya sebesar $83 \%$ dijelaskan oleh faktor lain yang tidak dianalisis dalam penelitian ini. 


\section{Daftar Rujukan}

A.J Romiszowski, 1981. Designing Instructional Sistem Decision in Course Planning (New York: Nicholas Publishing Company

Abu Ahmadi dan Widodo Supriyono, 2008. Psikologi Belajar, Jakarta:Rineka Cipta

Ahmad Asrori, 2009. Hubungan Kecerdasan Emosi dan Interaksi Teman Sebaya dengan Penyesuaian Sosial Pada Siswa Kelas VIII Program Akselerasi di SMP Negeri 9 Surakarta .Skripsi.Surakarta.: Program Studi Psikologi Fakultas Kedokteran Universitas Sebelas Maret Surakarta.

Anita Woolfolk.2009. Educational Psychology : Active Learning Edition. Yogyakarta; Pustaka Pelajar

Aununrrahman, 2012.Belajar dan Pembelajaran, Bandung: Alfabeta

Azwar, Syafuddin.1996, Pengantar Psikologi InteligensiYogyakarta: Pustaka Pelajar

Benyamin S. Bloom, 1970.Taxonomy of Educational Objective London: Longman

David M. Merrill and David G Twitcell, 1994.Instructional Design Theory.New Jersey: Educational Technology Publication Englewood Cliffs.

Dorothy C Adkins, 1974. Test Construction: Development and Interpreting of Achievement test .Ohio: Merriel Company

Elizabeth B. Hurlock .2005. Perkembangan Anak Jilid 2 .Jakarta:Penerbit Erlangga

Feldman, Robert.1987., Understanding Psychology. New York: Mc-Graw-Hill

Garrison, K.C. \& Magoon, R.A.1972., Educational Psychology : An Integration of Psychology and Educational Practices Charles E. Merril Publsing Company, Colombus

Goleman, Daniel.1995, Emotional Intelligent Why It Can Matter More Than IQ, New York: Bantam Books

Iswanti.Pengaruh Minat Belajar Dan Peran Orangtua dengan Prestasi Belajar Siswa SMU Tarakanita I. TARAKANITA Vol 2 No 2 / 176ISSN 1693-6744

LeDoux, Joseph.,1996. The Emotional BrainNew York: Simon \& Schuster

Leslie J. Briggs (ed), 1979. Instructional Design: Principles and ApplicationEnglewood Cliffs, New Jersey: Prentice-Hall Inc

Makmun, Abin Syamsudin.1996, Psikologi Pendidikan.Bandung: Remaja Rosdakarya

Muhaimin, dkk.1996.Strategi Belajar Mengajar. Surabaya: CV Citra Media

Muhaimin.2002. Paradigma Pendidikean Islam (Upaya Mengefektifkan Pendidikan Agama Islam di Sekolab).Bandung Remaja Rosdakarya

Muhamad Toyib Daulay. Pengaruh Kecerdasan Emosional Terbadap produktivitas Karyawan Pada Pt Sinar Inti Berkab Sejabteramedan. Jurnal Ilmiah Abdi Ilmu. Vol. 2 No.1 Mei 2009.ISSN : $1979-5408$

Muhibin Syah, 1997. Psikologi Pendidikan dengan Pendekatan Baru. Bandung: Remaja Rosdakarya

Mulyana, Rohmat. 2004. Mengartikulasikan Pendidikan Nilai.Bandung: CV Alfabeta

Nana Sudjana, 1995.Penilaian Hasil Proses Belajar Mengajar Bandung: PT. Remaja Rosdakarya

Norman E. Gronlund, 1978. Stating Objective for Classroom Instruction New York: Macmillan Publishing Co. Inc,

Nurdin.Pengarub kecerdasan emosional Terhadap penyesuaian sosial Siswa di sekolah . Jurnal Administrasi Pendidikan. Vol. IX No. 1 April 2009. ISSN.1412-8152 
Robert M. Gagne, 1988. Prinsip-prinsip Belajar untuk Pengajaran. Terjemahan Abdillah Hanafi dan Abdul Manan, Surabaya: Usaha Nasional,

Hamzah B. Uno, 2008Teori Motivasi dan Pengukurannya, Analisis di Bidang Pendidikan, Jakarta: Bumi Aksara

Robert M. Gagne, 1983.The Condition of Learning New York: Hot Rinehart and Winston Inc

Saifuddin Azwar, 2003. Penyusunan Skala Psikologi Yogyakarta : Pustaka Pelajar

Saifuddin Azwar, 2007. Sikap Manusia, Teori dan Pengukurannya. Yogyakarta: Pustaka Pelajar

Salovey, Peter \& D.J. Sulyster, 1997. Emotional Develompment and Emotional Inteligence New York: Basic Books

Sardiman A.M, 1996. Interaksi dan Motivasi Belajar Mengajar Jakarta: Raja Grafindo Persada

Slameto.2003. Belajar dan Faktor-faktor yang Mempengarubinya. Jakarta:Rineka Cipta

Strangman,K.T. 1996. The Psychology of Emotion, New York : Chichester, John Wiley \& Sons

Strangman,K.T. 1996. The Psychology of Emotion, New York : Chichester, John Wiley \& Sons

Sumadi Suryabrata.2008. Psikologi Pendidikan. Yogyakarta: PT Raja GrafindoPersada

Thorndike dalam Hamzah B. Uno, 2008. Teori Motivasi dan Pengukurannya, Analisis di Bidang Pendidikan Jakarta: Bumi Aksara

Winkel W. S. 1999. Psikologi Pengajaran, Cetakan II. Jakarta:Gramedia

Zuhairini, dkk.1995. Metodologi Pendidikan AgamaJakarta: Ramadhani. 